\title{
A Review of Diana Hunt's Economic Theories of Development: An Analysis of Competing Paradigms
}

\author{
Ahmad Sadiddin \\ Department of Economics and Management, University of Florence \\ Via delle Pandette, 32. CAP. 50127 (FI), Florence, Italy \\ Tel: 39-333-355-8295 (mob); 39-055-275-9573 (work) \\ E-mail: ahmad.sadiddin@gmail.com (personal); ahmad.sadiddin@unifi.it (work)
}

Received: August 13, 2014 Accepted: August 30, 2014 Published: September 19, 2014

doi:10.5296/ijch.v1i2.6132 URL: http://dx.doi.org/10.5296/ijch.v1i2.6132

\begin{abstract}
This essay presents an extensive review of Diana Hunt's Economic Theories of Development, aiming to expose the reader to the most important points of the book. The author starts by an introduction to present the economic heritage of the eighteenth and nineteenth centuries that formed the basis upon which the reviewed development economists constructed their models and theories. She then works to classify the economic literature under six main headings and moves to demonstrate the main elements of each paradigm, their contributions to the debate of development economics or to policy formulation before discussing the critiques levied against each. A final chapter of the book is devoted to comprehensive comparisons among different paradigms demonstrating potential points of similarities and divergences among each other, and possible influence from each one on others.
\end{abstract}

Keywords: Development economics, Paradigm, Intellectual framework, Critique, Debate, Policy formulation

Preface

Why reviewing a book of 25 years old? There might be several reasons for doing so, but I see the most important one is that in the last 20 years, development economics textbooks have been dominated to a large extent by one only theory: neoclassical economics, whether in its orthodox view or in one or more of it extensions such as neo-institutional economics and information economics. Despites all critiques levied against the weaknesses of this theory, whether related to its own theoretical flaws or to its failures as a guide for development 
planning and policy formulation especially in developing countries, things in academia have not noticeably changed. This book reminds us that neoclassical economic theory is not identical to economics especially when it comes to development economics. The book may push us to think that its current dominance may not be attributed to its theoretical riguruosity and scientific superiority as many of its proponents claim, but it may be due to the failure of alternative paradigms to survive, particularly in Western academic institutions, after the end of Cold War and the collapse of the "socialist bloc".

The review is structured in the same way of the book structure aiming to present a summary in a consistent manner to give the reader an idea on the most important points of each Chapter. The review is concluded by a comparative discussion of the book chapters before a final comment highlighting the relevance of the book for today.

\section{Introduction}

The purpose of the book, as stated by the author, is to elucidate the nature of the dominant perceptions of development and underdevelopment that commanded, for varying periods of time, widespread support and helped generate important developments in the theory of development economics or/and guided economic planning and policy formulation. The book was intended to be a complement to textbooks in development economics in which she aimed at outlining the main intellectual frameworks that have guided the thoughts and the policy recommendations regarding development processes in most developing countries.

Of course, the work is not original! Since the seventies a plenty of writings have emerged on schools of thought in development economics. However, what makes this text distinct is that it is not only addressed to development theorists but can be broadly used as a fruitful reference by development practitioners and students. Such a book helps overcome many misunderstandings that may result from standard textbooks as the latter analyses policy and development issues by drawing from economists belonging to different intellectual frameworks, who may not only use different analytical methodologies (and sometimes contradictory) but may also assign different concepts to the same terms. Such a textbook helps clarify such differences by focusing on the intellectual perspectives, their main features and the differences between them.

The book starts by an introducing chapter in which the author justifies the use of the term paradigm as a synonymous of intellectual framework, which is to be used as a sorting device and a basis for the exposition of each framework. In this regard, she adopts the Kuhnian definition of a paradigm (Kuhn, 1962):

"the constellation of values, beliefs, perceptions of empirical reality, which together with a body of theory based upon the foregoing, is used by a group of scientists, and by applying a distinctive methodology, to interpret the nature of some aspect of the universe we inhabit."

When applying the term to the thoughts and interpretations of development and underdevelopment, however, the author adds three other elements to the definition for a bulk of literature to be singled out as a paradigm. In her view, the literature must have commanded the support of significant group of scholars, generated further theoretical development after 
their primary articulation, and been applied to practical activity such as economic planning and policy formulation. By this, the author attempts to indicate the broader context in which the different paradigms have emerged and to outline the main drives and purposes behind their primary articulation.

In addition to the introduction, the book contains more 10 chapters. Two of them are devoted for theoretical backgrounds and heritage of economic thoughts and debates on development economics from its emergence. In this context, she singled out and summarized six main paradigms plus a semi-one (dependency analysis). Later in the book, each paradigm is discussed extensively in a separate chapter. A concluding chapter is an interesting comparative summary of the singled out paradigms.

\section{The Economic Heritage}

The author devotes the second chapter of the book to the heritage of the economic thoughts and debates that emerged in the eighteenth and nineteenth centuries and made the ground for the emergence of development economics in the 1950s. The similarities between the western economies of the eighteenth and nineteenth centuries and those underdeveloped now pushed many development economists to draw their principal concepts from theories of classical economists. Therefore, the review of the economic heritage is conducted in a way that explains the various aspects of economic development together with main determinants in different temporal and spatial contexts, highlighting the conditions that made some thoughts and perspectives predominant in some periods and some others applicable in contexts different from the ones in which they originally emerged.

In the discussion, the author treats the heritage chronologically after classifying the dominant theories and models under broad headings from Adam Smith to the neoclassical economists. Smith, together with Malthus, Ricardo, and Mill are classified under the heading of classical legacy. According to this legacy, the most notable features of economic development (that was not then differentiated from economic growth) are the importance of market expansion, the importance of profits for new investments, the need for trade liberalization as means of market expansion to allow the exploitation of comparative advantages, and the importance of technological progress in raising labor productivity.

The author then extends the discussion to Marxism and how it emerged in interaction with the classical legacy. In her discussion of the classical Marxist perspective, she mainly relies on the works of Marx with some of Lenin's extensions on the theme of imperialism. According to this classical Marxist perspective, what makes capitalism distinct from earlier modes of production is the capitalist's drive to accumulate wealth through productive investment. This drive leads the capitalist to search constantly for means to raise profits and undercut competitors. But capitalism is also based on antagonistic relationship of two classes, capitalist and proletarian. The former owns means of production, exploits the labor force of the latter, and appropriate its surplus to be used for further accumulation. As individual capital expands, in association with technical progress, plant size rises and labor becomes more specialized and routinized and also increasingly interdependent. In the meantime, workers become increasingly alienated from the labor process and the capitalist class. All of 
this together with anarchic nature of capitalist competition, the capitalist mode of production experiences periodic crises caused by declining profits (due to competition) and by recurrent phases of over-production and under-consumption that lead to laying off labor and falling of wages. Consequently, Marx expected that a final crisis would lead the labor class to appropriate means of production and establish a new egalitarian mode of production. Lenin, however, has doubted that capitalism will expand in the colonies in the same way it did in the imperial countries, planting seeds for a new Marxist perspective on development.

Although the author explicitly treats Schumpeter, Keynes, Harrod and Domar as extenders of the classical legacy, she prefers to deal with them separately due to their distinct contribution on economic theories of development that sometimes sought to break with the classical legacy. Schumpeter's main contribution is the distinction between growth and development. While growth is a slow process resulting mainly from reinvestments in additional capital financed from profits, Schumpeter defines development as an innovatory dynamic process in which the main actors are not capitalists reinvesting profits, but the entrepreneurs perceiving, implementing and exploiting opportunities for using existing resources in new methods. With respect to Keynes, or the so-called the Keynesian revolution, its main theoretical contribution was Keynes's theorization of the causes and potential policy solutions to the problem of unemployment. But with respect to development economics specifically its main contribution was its influence on Harrod-Domar growth model. In the latter model, the rate of guaranteed growth is given by planned savings rate divided by planned capital:output ratio. The model predicted periodic deflationary pressures in Western Europe and North America due to short-run variations in capital:output ratio followed by adjustment in investment plans. These variations are the consequence, among others, of the fact that current investment plans are largely independent of current savings and consumption plans meaning that there is no certainty that output will grow at the warranted rate.

\section{The Emergence of Development Economics}

In the third chapter, the author states how development economists, inspired by the former dynamic theories, started to confront a number of controversial issues, among which the most important are the following: 1) Is the world trade system, given the superiority of advanced countries in technology, necessarily in best interests for developing countries? 2) What is more important: raising savings or solving the problem of market imperfections? 3) How savings must be increased? Mainly from capitalist profits? 4) Is it a reasonable assumption that underdeveloped counties can repeat the same path of development pursued by industrially advanced ones?

Of course, differences were great not only in the way development theorists tried to answer these and other related questions, but also in the ability to apply pre-existing theories to the analysis of development and underdevelopment. These differences, which emerged also due to different temporal and spatial contexts, made the land for the emergence of several paradigms on the topic of development and underdevelopment, according to the author. In her sorting of the various contributions of development economists, she used the following criteria: 1) contributions must have a distinct interpretation of the essential nature of 
development and underdevelopment, 2) must have fundamental elements in common in their specification of key causes of development and underdevelopment. Then a set of contributions is classified as a paradigm when: 3) the features specified in 1 and 2 have obtained the support of a significant number of scholars, and 4) the initial articulation of the thoughts has given rise to further theoretical development and has guided more practical action in planning or policy formulation.

Using the criteria defined in the last paragraph, the author traces the contexts in which development economics from the fifties first emerged whether in Western Europe and North America or in Latina America, which gave birth to modernization theory and structuralism respectively. The author explains how the consequences of the Great Depression of 1929 and the World War II on the economies of Latin America, with the consequent declining terms of trade of agricultural and other raw materials, pushed Raoul Prebisch (1949) to re-examine the theory of comparative advantages and Laissez-Faire doctrine. The works of Prebisch, who was first trained according to neoclassical theory and became in late forties the director of Economic Commission for Latin America (ECLA), together with the extensions of other ECLA economists such as Furtado and Sunkel, gave rise to the school of structuralism in economic thought. Simultaneously in the context of the successful completion of Marshall Plan in Western Europe, many western economists started to concentrate their research on underdevelopment as a consequence of political pressure to advance development in newly independent Arab and Asian countries in order to achieve international stabilization and contain communism. This line of thought gave birth to the so-called modernization theory in development economics and what the author prefers to call it the paradigm of "expanding capitalist nucleus". The author considers Rostow (1953) and Lewis (1954) to be the main founders of this paradigm but does not ignore the contributions of others such as Rosenstein-Rodan (1943), Nurkse (1953), Myint (1954), Myrdal (1957), Hirschman (1958) and others.

Despite the fundamental differences between the two perspectives, the author picks several essential points in common. First, they both reject the neoclassical theory principles on static comparative advantages and they both consider development as an accumulation and distinct process from growth in the same way as it was viewed by Schumpeter. They also regarded industrialization as the key to development, and this cannot be achieved by continuing to rely on importing manufactured products and exporting raw materials as the neoclassical theory recommends. Moreover, they both emphasized the existence of both open and disguised unemployment and so an important aspect of development lies in mobilizing this unemployed labor into productive activities. However, the most crucial common element between the two perspectives remains that they both regard the government to play a central role in resource mobilization together with current operation of market forces.

On the other hand, the author sees that the most important difference between the two perspectives lies in how they analyze underdevelopment and what are its ultimate causes. While structuralists attributed underdevelopment to the structure of world trade system that blocks the development in the poor countries (periphery) for the benefit of industrial ones (the center), the advocates of expanding capitalist nucleus saw the crucial constraints to 
development to be laying in the indigenous institutions and attitudes that have caused, among others, the very low rate of saving. The latter is seen the overriding constraint to development by many proponents of this paradigm.

Then the author traces the growing criticisms against both perspectives that started in the sixties from left and right. The left criticism argument emphasized that after e decade of capital accumulation and import substitution the conditions of masses in the Third World have remained as before or worsened. This line of criticism has given rise to the neo-Marxist paradigm. On the other hand, some criticism, mainly coming from the right, focused on the widespread inefficiency in resource allocation that accompanied the process of maximizing capital accumulation and the promotion of import substitution programs. This line of critics has given rise to the revival of neoclassical paradigm in development economics.

The author acknowledges Paul Baran (1957) to be the founder of neo-Marxist paradigm in development economics as he was the first to observe the relevance of Marxism to the analysis of underdevelopment despite his observation that Marx was over-optimistic concerning the prospects of capitalist development in the colonies. This pushed him to draw his fundamental inspiration directly from Lenin and his contemporaries. The author, while describing the context in which the neo-Marxist paradigm emerged, illustrates its similarities with the structuralism. The core element of similarity is in the way they both view the ultimate causes of underdevelopment, which according to both paradigms lie in the structure of world trading system. However, while structuralism emphasizes the existing economic structures of the underdeveloped economics to be the immediate cause of underdevelopment, neo-Marxist paradigm regards the pattern of class control over the economic surplus to be the immediate cause. This difference gives birth to the fundamental difference in the conclusions. Structuralism aimed to play an active role in policy reform within the international economic system, while neo-Marxist paradigm concludes that the only path to development is through withdrawal from international capitalist system to take a socialist development path based on masses' control of economic surplus after ending the current class alliances in the countries of the periphery. In other words, neo-Marxism is more politically radical calling for revolutionary change while structuralism had accepted the fundaments of capitalist development.

The author then illustrates how the criticism that the neo-Marxist analysis faced, after the observations that some capitalist-based development had been occurring in a number of periphery countries, has led the latter, especially through Amin (1974) and Frank (1978) to respond using a term that was already used but not sufficiently emphasized: dependency. These two neo-Marxists, and others, used "dependency" to characterize some undesirable properties of the occurring development. Here then, according to the author, happened the birth of the widely called "dependency school". However, the author prefers not to treat it as a separate paradigm due to mainly two reasons. First, it lacks a common departing ground since it emerged from different several schools and not only from neo-Marxism. In this regard, the author describes also the contribution of some proponents of the structuralism on cultural dependence that leads to economic one. The second reason is that during the seventies a body of literature started to prove that dependent development is not only possible 
but it is occurring in reality and may lead in the future to the breaking of undesirable dependent relations. Consequently, no common policy implications were associated with dependency analysis.

With regards to the revival of the neoclassical paradigm, the author states the difficulty in analyzing its contribution to development debate as its proponents usually focuses on particular issues but rarely start with a statement of first principles such as a definition of development. She attributes this to an implied assumption held by many neoclassical economists that these first principles are given i.e. already known, while emphasizing that many others regard it to be the task of government to set development definition and objectives while the role of economists is confined to prescribing the most efficient way of achieving these objectives.

In addition to the already framed four paradigm plus a semi one (dependency analysis), the author singles out two additional paradigms: the basic needs approach and Chinese development experience of 1949-1976 (the Maoist paradigm). These two paradigms appeared in the seventies when the Marxian analysis of development and underdevelopment was so popular among young development economists, but they were preceded by a literature that attempted to redefine development based on refusing the necessity to accept the increased inequality together with rising growth in the first phases of development. However, this line of thinking was in the meantime unwilling to accept the political conclusions of neo-Marxism. These issues were widely discussed in academic institutions and some branches of the United Nations. The debate has pushed towards the redefinition of development according to Seers (1972) to take account of trends not only in growth but also in poverty, income distribution and employment.

This context has created an interest in the West of the Chinese development strategy pursued during the Maoist period, and it was explicitly formulated by Lefeber (1974) who argued that if demand needed to support growth and industrialization is to be created internally, this can only be achieved by raising incomes and production in the agricultural sector that contains most Third World population. His main recommendation was, thus, to combine income redistribution with output expansion through the redistribution of land rights and the creation of communal framework of rural production along the Chinese lines. The author tries then to link 'the basic needs approach' to the Maoist development experience despite its proponents' emphasis that growth combined with absolute poverty elimination can be achieved in a market economy context, citing Taiwan and South Korea as examples.

\section{The Paradigm of the Expanding Capitalist Nucleus}

This paradigm was principally articulated by a number of economists, formally educated according to the principles of neo-classical and Keynesian theories, but early realized their shortcomings for developing countries. Neo-classical theory assumes full employment of resources and have not presented a comprehensive thesis to approach development since it has only focused on short-term questions as development is assumed to be guaranteed in the long-term. These assumptions certainly do not hold in the contexts of developing countries; neither do some assumptions of the Keynesian theory such as the existence of unlimited 
production factors in the short-run in addition to the Keynesian assumption that the most important barrier to development is the increase in savings that will not find reinvestment opportunities. Therefore, Lewis found it useful to return to classical literature of the eighteen and nineteen centuries that departed from the assumptions of limited resources, coupled with abundant labor force receiving very low wages; economic characteristics similar to those present in most developing countries.

The author summarizes the paradigm relying mainly on the work of Lewis (1954), who was convinced that the most influential cause of underdevelopment is the lack of savings to be reinvested. Therefore, he started analyzing developing economies assuming that they are composed of two main sectors: one large but poor and mainly based on peasant production, characterized by considerably unemployed labor force; while the second is small but profitable and advanced and based on capitalist investments. This modern sector expands and reinvest the profits and continues to absorb the abundant labor force from the peasant sector. According to this line of thought, capitalists are considered the pillar of development process since their capacity to save and reinvest savings are the highest. Lewis assumed that peasants and workers can hardly survive due to their very low wages and landlords have a high propensity to consume, and when they save they invest the savings in purchases of new land and/or already existent investments.

Thus, only capitalist class can save and reinvest savings in newly created projects that increase output and employment. However, Lewis did not hesitate to support state capitalism once he recognized the capability of governments to accumulate capital through mobilizing profits and taxes to reinvest it in suitable productive activities. The author at the end of the chapter provides a description of a 'socialist version' of this paradigm describing the Soviet Union development strategy under the rule of Stalin.

The author notices the optimism of the theory through its implied expectations over the prospects of development according to which once the modern sector emerges, development becomes a question of time and its pace is only conditioned by technological advances in the modern sector. This optimism is not affected by Lewis's expectation that the beginning of capital formulation will probably depends on foreign sources!

Policy implications of this paradigm was majorly in line with the capitalist framework through relying on market forces as mechanisms for economic organization, but it diverted from neo-classical theory in recognizing a leading role of governments particularly during early stages of economic growth. It was also characterized by its bias against agriculture to guarantee the continuous flow of cheap labor to the modern sector that was necessary to encourage investment. It also recommended strict control over imports with the exceptions of technology and capital whose imports were encouraged. With respect to monetary and fiscal policies, it emphasized the importance of money expansion and decreased interest rates to boost investment.

The author extends the review to cover other contributions starting by Rostow (1953) on stages of growth discussing in some details his concepts of 'take-off' and 'leading sector' (Rostow, 1956). This is followed by discussing the extensions of Ranis \& Fei (1961) on 
transition to self-sustained growth and contributions of many others on investment criteria, technical choice and savings mobilization. At the end, she summarizes the main criticisms levied against the paradigm.

The main weakness of the paradigm according to the author is the model's heavy reliance on closed economy assumption. Nowhere in the models of Lewis, Rostow, or the others, was a discussion of the mechanisms in which technology is transferred to and adopted in a poor underdeveloped country. The import of technology will probably keep the importing country dependent on the technologically advanced countries as production activities may have few or no forward and/or backward linkages especially when it comes to heavy industries. This can certainly exacerbate the balance of payments deficit and deprive the developing economy of the multiplier effects of backward and forward linkages. The paradigm totally ignores the question of internal low demand and its potential impact in savings. It consequently predicts that although growth will occur certainly in the short-run it will only bring improvements to the masses in the long-run when the capitalist modern sector becomes dominant.

The theory ignores the existence of external factors constraining development such as difficulties in obtaining hard currency to finance imports of technology, and it instead emphasizes the internal obstacles to development especially the social structure and the present social institutions. But its analysis was confined to the role of this internal bodies and relations in accumulation of savings, being the main drive of development. It never approached the question of internal obstacles from policy perspectives that aimed to change the institutional settings in ways other than expanding the capitalist nucleus.

\section{The Structuralist Paradigm}

Structuralism started from the criticism that targeted neo-classical theory especially its advocacy of free trade and comparative advantages. On the other hand, its proponents did not accept the proposition of the expanding capitalist nucleus paradigm that low saving is the main barrier to development. Structuralism instead emphasizes the importance of economic incentives, which require the availability of foreign currency to purchase the necessary capital goods. According to the author, structuralists characterize underdeveloped economy by low per capita income coupled with structural properties related to production, employment, capital stocks, economic institutions, and agricultural systems that prevail in the economy and their impacts on demand and supply elasticities. Such an economy is characterized by a backward agricultural sector of low productivity and a modern but small sector using high technologies. The latter is usually specialized in the production of raw materials for exports, is very open to foreign markets upon which it relies for equipment and technology, and owned by a class whose consumption relies mostly on imports. The agricultural sector on the other hand is governed by land tenure and investment regulations that limit its expansion. This means that the economy as a whole faces great difficulties in expanding output due to the absence of economic incentives that result from the dual structure and the predominant property and productions systems, and due to the continuously increasing demand for imports as incomes rise or/and population grows.

Therefore, the structuralists regards government intervention the key to sustainable 
development through the restructuring of the national economy to allow the domestic producers to change their structural properties and move to the production of import substitutes, and to create common markets among neighboring countries enabling the domestic industries to diversify the domestic output and become able to achieve sustainable development. Land reform is thus considered a key policy instrument but the most important ones are the imposition of levies and taxes on imports and the rationing of foreign currency to serve the restructuring process. Similar to the expanding capitalist nucleus, structuralism also recommends low interest rates and some tax exemptions in important sectors. Foreign investment is welcome as a source of finance and technology, but must not dominate the economy.

Given the above, structuralism, differently from the paradigm of expanding capitalist nucleus, emphasizes that current developing countries cannot repeat the same development path pursued by the advanced countries of today. This is due to its present marginal position in the international economy, named "periphery" in structuralist terminology, in which it is always exposed to strong competition by the industrial "centers" that did not face a similar condition at the beginning of their economic development. However, structuralists believe that developed countries can assist the developing ones by opening their markets and providing financial aids to fill the gaps in foreign currency required for the structural transformation of the economy.

The author emphasizes the reliance of structuralism on Marxian analysis of capitalist system in the west and its crisis due to the alternation of labor wage rises and inflation with economic recession as was predicted by Marx. In this respect, structuralism regards the capitalist expansion through the colonization movements, by the end of the nineteenth century, to endure the main responsibility of underdevelopment in the periphery. This expansion allowed the advanced centers to enter into economic relationships focused on raw materials with the periphery, creating in the latter the dual economies described above. This analysis leads the structuralists to predict, differently from the modernization theory, that the profits generated by the capitalist sector will not be reinvested in the domestic economies. This last point is the basis for which structuralists justify government intervention to generate incentives for domestic investments through protection and rationing of foreign currency, coupled with expanding internal markets through the formation of common markets with neighboring countries. In this context, public sector produces import substitutes that have high income elasticities to maximize the benefits of multiplier effects to help create forward and backward linkages to strengthen the economic cycle nationally or at least regionally among neighboring underdeveloped countries.

However, and despite the similarities between structuralism and the traditional soviet Marxism in their regard to the importance of state role in development process, the author picks fundamental differences in the way they regard the role of markets. While soviet Marxism gives the highest priority to heavy industry, the latter comes at the end in the ranking of industrialization priorities of structuralism that gives the highest priority the medium and small industries. A difference that is attributed to the high reliance of structuralism on market that was much less important in centrally planned economies. 
But the most important contribution of structuralists, according to the author, is the criticisms they levied against the comparative advantage theory advocated by the neo-classical economists. Prebisch (1949) considers this theory to be superficial and static and fails to account for significant differences in labor productivity amongst different countries. In his criticism Prebisch goes beyond positive economics to enter in the analysis other elements such as political relations and the roles of labor and trade unions in the advanced centers. The latter according to Prebisch plays important role in preventing the decrease of wages during economic crisis in the centers, putting more pressure on wages in the peripheries who lack such effective unions. In this way, advanced economies do not only benefit from its increased productivity but also absorb part of productivity increase in the peripheries. Prebisch also assessed the effects of political changes at the international level, emphasizing that at the end of the nineteenth century the UK, that was the greatest industrial power, imported most of the raw materials opening opportunities for the peripheries to earn considerably from their exports. But the elevation of the USA that imports very small proportion of its required raw materials has weakened the international demand and caused substantial price reductions of raw materials with consequent negative impacts on the exporting periphery countries.

Singer (1950) elaborated this last point by extending the analysis to the income elasticity of demand, stressing that it is low for raw materials and high for industrial products. This means a rise in income level of advanced countries will bring a proportionally small increase in their imports of raw materials while a small rise in incomes of underdeveloped countries will bring a proportionally high increase in their imports of industrial products turning the terms of trade in favor of the industrial centers. This tendency is strengthened, in the centers, by technological advances that enable industries to use cheaper substitutes and reduce their input requirements, while continuing to undertake strict protection measures on agricultural imports.

Structuralists also criticized strongly the monetary policies that the neo-classical theory recommend and are majorly based on currency devaluation to overcome balance of payments deficit and inflation. They claim that these recommendations do not hold at least under three conditions: when income elasticity of exports is low as explained above, when export sector is owned by foreigners so domestic production will not expand, and when most imports are capital goods with the consequence of negative impact on productive sectors.

Structuralists differ from neo-classical economists with regard to inflation as they do not consider it to be an autonomous phenomenon. It is rather a consequence of the imbalances that come out during the first stages of growth due to the limited short-run supply with an increased demand. They suggest that governments can help contain it by foreign borrowing, by directing more investments towards economic sectors with high supply elasticities, and by performing institutional reforms such as land reform in order to improve supply elasticities.

Concerning taxes and wages policies, structuralism contradicts with advocates of expanding capitalist nucleus. It refuses taxing agriculture (to ensure the flow of cheap labor to the modern sector) and recommends a gradual increase in labor wages to guarantee market expansion, increased productivity, and detention of productivity benefits within the national 
economy. Instead, it recommends taxing luxury products and imports and encourages the production of substitutes. This means imposing progressive taxes on consumption and giving tax exemptions to investment. Government expenditure must be concentrated on infrastructure avoiding spending much on services in the early phases to reduce inflation and motive the accumulation of capital.

With regard to the choice of technology, structuralists consider it to be neutral and recommends the adoption of most advanced ones, giving priority to the industrial sector as it regarded agriculture as a source of raw materials and foreign currency.

As mentioned earlier in this paper, the author distinguished two main sources of criticisms levied against structuralism: one from the neo-classical economists (right) and one from the neo-Marxian (left). The neo-classical criticisms did not give much space to the theoretical basis but focused on potential consequences of some of its recommendations. Namely, they expressed concerns for potential inefficiency in resource allocation due to the import-substitution program. The neo-Marxists criticism although were in general agreement with its theoretical basis, they rejected its policy recommendations and considered them 'too reformist'. They claimed that structuralists ignored the role of multinational corporations in controlling the patterns of investments in the periphery. According to the neo-Marxists, multi-corporations use largely capital-intensive technologies that do not absorb enough labor resulting in continuous dependence on imports for technology and the ever-lasting of dual economies. In addition, they claimed that these corporations generate consumptions patterns among upper-middle classes that motivate consumption of capital-intensive imports with consequences of worsening balance of payments and creating social tensions among different social segments.

\section{The Neo-Marxist Paradigm}

The author starts the discussion of neo-Marxist school with a statement of its ambition which is to analyze the process of economic development in Asia, Africa, and Latin America; a subject that was briefly treated by Marx, but was later extended by Lenin, Bukharin and Luxembourg. The author recognizes the neo-Marxist economists to be distinct from other development economists in the fact they were all politically involved exactly as the fathers of Marxism. And their mission was in principle to demonstrate the exploitive nature of capitalist world system with the purpose of mobilizing support to make revolutionary change. But in the meantime, they were academic researchers who submitted their papers and contributions for scientific discussion to demonstrate the ultimate causes of underdevelopment.

According to the author, neo-Marxists depart from a precise definition of underdevelopment which is the continuous flows of economic surplus to the advanced centers from the periphery. This surplus is calculated to be the difference between the actual or potential production and the actual or basic consumption. In this system, the periphery countries have low incomes and slow capital accumulation rates with the consequences that the surplus is not reinvested domestically and national income does not rise with negative consequences on equity. In such a system, the possibilities of development is determined according to the position of the relevant country within the international economy plus the nature and the historical evolution 
of class control over the economic surplus inside the relevant country.

The neo-Marxists explain this flow of surplus as a result of unequal exchange trade system that was imposed by the advanced countries in the past after destroying the artisan production and eliminating the incentives for indigenous capitalist industrial development. This system is still responsible of preventing development in the periphery as it continues to deter the current attempts of industrial development with competition originating from the center's industrial exports. Accordingly, the development that occurred primarily consists of a small number of industrial monopolies owned by local or foreign capitalists who send their profits to the centers. In addition, the predominant classes both in the centers and in the peripheries do not have any interest in autonomous development in the peripheries due to the major sources of these classes' incomes. Consequently, the neo-Marxists predict that underdeveloped economies cannot repeat the development path of currently advanced economies because the international conditions changed completely and irreversibly. They believed that the competitive phase of capitalism, its most dynamic phase, was cut in the periphery by means of foreign competition, and therefore, the only path to development will start by the occurring of revolutionary political change.

Different kinds of criticisms have been levied against the neo-Marxist analysis of underdevelopment. One was based on fact as it confirmed that possibility of successful capitalist development is not so low, and some industrial attempts were actually successful. Another kind of criticism focused on the relative neglect of the neo-Marxist analysis of domestic contradictions while focusing too much on contradictions with external powers. However, the most relevant criticism according to the author was maybe the one that emerged inside Marxism. This appeared in the seventies and stated that it is impossible to reach decisive conclusions about the potentials for capitalist development in the peripheries that hold true for all. The differences between the periphery countries are great in terms of location, resources, historical heritage and social structure.

\section{Dependency Analysis}

The author defines dependency studies as those focused on relationships between the centers and the peripheries that prevent partially or totally development in the latter. The author traces these studies to two main sources: the neo-Marxist studies that emerged in the seventies as responses to some criticisms levied against the neo-Marxist analysis of underdevelopment, and the late works of structuralists especially those of Furtado (1976) and Sunkel (1973).

Among the neo-Marxists, Dos-Santos (1970) and Amin (1974) define dependency as a relationship between advanced centers in which economic development comes out from internal dynamics and the peripheries where development is a consequence of capitalist expansion of the centers with negative or positive implications for the peripheries. This means that dependency is not mutual, it is rather one directional relationship. This is because the advanced centers have developed internal dynamics to absorb crisis through increasing real wages to expand consumption and creating new forms of investments to absorb increased capital by means of reinvestments in luxuries, military forces, and advertisements. This is to 
say that the surplus of the peripheries that flows to the centers is not anymore a necessary condition for development in the latter as was apparent in the previous neo-Marxist analysis. The neo-Marxists defined three forms of dependency: trade/commercial to secure foreign currency for the periphery, financial to continue to gap the deficits that result from the periphery's weak position in terms of trade, and technological since the peripheries need the technology controlled by the monopolistic corporations of the centers.

Therefore, the Marxist thesis on dependency focused on the idea that the world is governed by one world capitalist economy that leads to the development of production modes in the centers and weakens the positions of the peripheries so that their development, if occurs, is characterized by dependency on the development in the centers. Therefore, they confirm their pre-position that the only path to development remain in decoupling from the centers.

The structuralists' focus with regard to dependency was more on the cultural aspects of dependency and they defined cultural dependency to be a culture that motivates consumption and reduces the ability to make the necessary savings for capital accumulation and reinvestments. They focus in the analysis on the role played by the multi-corporations that allow limited industrialization in the peripheries and block the Third World in a position of technological dependency and technical backwardness. However, structuralists never introduced potential solutions to deal with dependency as the neo-Marxists did.

The author regards that the most important criticisms levied against dependency analysis came from Seers (1981) who stated that dependency school ignored many important characteristics such as population, ethnic and linguistic homogeneity, geographical location, and composition of natural resources. He also refused the assumption that dependency by itself determines the development paths, but believes instead that a political leadership has a lot to do to change the rules of game. Other development economists such as Cardoso and Faletto (1979), despite their general agreement with neo-Marxist and structuralist analysis, has stated that dependent development is not only possible but it is actually taking place in many countries. So that there is no a general rule that fits all and it is the particular condition of each country that determine the final result. Warren (1980) has criticized some dependency assumptions saying that there are at least three commodities (wheat, oil and technology) that all need, meaning that there is no single country that is not economically dependent.

\section{The Maoist Paradigm}

The author starts the eighth chapter by posing the question of 'why studying the maoist paradigm in development?' She gives two reasons that made this paradigm distinct. The first is that it emerged and evolved in one specific country: the People Republic of China. The second is that it was not just a theory in development but was also a process of transformation at socio-economic and politico-ideological levels, characterized by advances in material welfare in a society based on equality. Accordingly, the author justifies her interest in the Maoist paradigm by making two important points. From the one hand, the Maoist experience introduced an applied model of Leninist Marxism in a backward country different from its Stalinist interpretation. On the other hand, many of its intellectual elements were influential outside China and outside the 'official socialism' at theoretical and practical levels. Among 
these elements is the strict linkage between political, economic, social and ideological views, whereas many development theories were criticized for their neglect of non-economic factors.

The author then moves to describe the miserable circumstances of Chinese economy when the Communist Party rose to power, and how, due to lack of experience, China followed at the beginning the Soviet development model relying heavily on central planning and authoritarian socialism. This model regarded development to be equivalent to heavy industrialization that was, due to limited resources, always funded by the surplus of agricultural sector. The model achieved high rates of growth for a decade due to rehabilitation of infrastructure (especially the irrigation networks) and land reform. However, since these things can be done only once, the plan faced new challenges especially population growth and declining rural incomes that raised fears of tensions with rural population who were considered the main supporters of the revolution.

The author describes how this fear led the Party Leadership to review the Soviet experience and how Maoism was founded particularly in this context. The review relied, accordingly, on four main points that the author considers to be the foundations of Maoism. These are: the intellectual heritage of Marxist figures especially that of Marx, Angles and Lenin, the practical experience of Soviet Union in the first three decades, the practical experience of Chinese Communist Party in masses mobilization and local management in the Northern part of Country during the civil war, and finally the background and the personality of Mao himself.

The Chinese revision of Soviet experience summarized the latter into six main points from which the Chinese kept only one: the priority of developing heavy industries. But contrary to the Soviet experience, the Chinese adopted the following principles: self-reliance, decentralization, antagonism to bureaucracy and elitism, discipline and common goals, non-material incentives, and the participation of masses in all aspects of social and economic activities. In this context, the author describes Mao's major contribution to be his insistence on listening to the peasants and considering their suggestions seriously, founding in this manner the so-called 'masses line', which was based on taking the dispersed ideas of masses, exposing them to reformulation to bring them back to be explained to the masses themselves, and lastly revising them after implementation.

The author summarizes the objectives of Maoism under four main titles. The first focuses on increasing material welfare and eliminating income differentials through and common employment of production means. The second confirms that heavy industry is a priority but its development should depends on the availability of surpluses from other sectors. This, thirdly, means that agriculture and manufacturing are also priority sectors and must be developed, in a parallel manner, to heavy industry, as they contribute to the improvement of masses incomes and capital accumulation. Last but not least, a priority must be given to achieve political and economic equality among different regions of the country through giving more proportion in industrial investment to the backward regions, enhancing self-sufficiency at the regional levels and giving more autonomy to the regions on 
decision-making.

It was in this context, that Maoist philosophy of 'walking on two legs' has appeared, the author confirms. This philosophy has diverted not only from the Stalinist Marxism but also from the expanding capitalist nucleus paradigm and from structuralism. The latter considers heavy industry to be at the bottom of priorities, while Maoism, despite its high appreciation of the light and medium industries, kept heavy industry a condition for sustainable development and a necessity for the catch-up with the more advanced countries. It also diverted from the paradigm of expanding capitalist nucleus together with Stalinism in that the Maoism refused the principle of keeping rural incomes low to guarantee the continuous flow of labor in the early phases of growth in the former and to extract the agricultural surplus to fund heavy industrialization in the latter.

The author summarizes the criticism levied against Maoism to be between total rejection and accepting only some of its elements. The neo-classical economists considered it to be an example of inefficiency and violation of political and economic freedoms. The partial criticisms instead differed substantially among researchers to a point that made it difficult to distinguish schools. However, most of these criticisms recognized the achievements of Maoism but affirm that the cost was so high and sometimes difficult to justify.

The author ends the chapter with a discussion of the Chinese experience particularity and again poses the question of its relevance to be reviewed as a development paradigm. She reviews how it was treated by many development economists, so that some proposed exporting the model due to its economic successes regarding the catch-up, while others proposed to use it as a general theoretical guide only. But many proposed only to adopt some elements and leave others due to its particularity that it was never a theoretical framework but it was developed through implementations that had implications for economic thought. The most important element proposed to be adopted by other countries was the principle of 'walking on two legs' for which was, according to the author, the most influential element of Maoism where it proved the possibility of growth with equity, contrary to most economic paradigms, and it basically in this element that Maoism influence the so-called 'basic needs first' paradigm.

\section{The Basic Needs Paradigm}

The author starts Chapter 10 by introducing the so-called 'the basic needs first approach', which considers combatting poverty, unemployment and significant inequality a principal component of any development process. This implies that growth of national income by itself is not equivalent to development if not accompanied by reduction in poverty and unemployment and an increase in equality, although growth remains an important pre-condition for development. This new definition of development has evolved into a paradigm after the accumulation of evidences from research and experiences in the non-socialist world proving that development policy based on the 'expanding capitalist nucleus' led always to increased poverty and inequality although national income rose. Many of these studies noticed that development processes even when growth was very high did not benefit the poor unless governments intervened in their favor. This resulted in the emergence 
of e new strategy in development that does not account only for growth as a measure of development but considered also distribution so that the new strategy was called the strategy of 'growth with distribution'.

The author considers Lefeber (1974) to be one of the most important theorist of the new approach who stated, in line with other paradigms (e.g. structuralists and neo-Marxists), that developing countries cannot follow the same development path of the presently advanced ones. This is because they do not have colonies to which they can export their surpluses and from which they can extract cheap raw materials. Lefeber goes more in depth with his thesis in line with structuralists when he confirmed the needs not only for increased savings but also for markets creation and expansion internally. But he then diverted from structuralism to present a Maoist policy prescription based on land redistribution, rural infrastructure construction, and the adoption of labor-intensive technologies to be followed by a development phase balanced between agriculture and industry.

The author quotes also other theorists upon whom the influence of Maoism was apparent even they did not express it explicitly. Adelman (1975), for example, proposed a strategy based the redistribution of economic assets especially land, total mobilization of human capital including simple unskilled labor, and fast growth through the intensification of resources employment using suitable technologies. She took the countries of Israel, Japan, South Korea, Singapore, and Taiwan as examples. However, the author states that it was due to the Dag Hammarskjöld Foundation Report in 1975, whose proposals were elaborated and presented by the ILO Director in the 1976 World Employment Conference (Look for a reference in the book), that the concept of 'basic needs' was brought into the forefront of development debate. In that report, basic needs were classified in four categories: 1- food, shelter, and clothing; 2- access to essential services such as safe water, education and health care; 3- adequate jobs for those able and willing to work, 4- needs of qualitative nature such as healthy environment, participation in decision making, and individual freedoms.

The author then moves to discuss how 'basic needs' were used as an operational target quoting some contributions of Morris \& Liser (1977), Grant (1978), Stewart (1985) and others. After that, she summarizes how the approach of 'improved public services' was sought by the World Bank and others to minimize the extent to which a focus on meeting basic needs requires radical political change. In this context, a reformist version of the approach was dominant, so that 'basic needs' were more-less interpreted to be equivalent to 'improved public services' so that no radical political change is a pre-condition for its success.

However, it is the more radical perspective on meeting basic needs that led to its emergence as a paradigm. But the most important characteristics of this paradigm are not its theoretical foundations, they are rather its policy implications mentioned above. In terms of theory, the paradigm does not have a new set of theoretical constructs, but its arguments are innovatory because they turned old assumptions on their heads especially those related to the propensities of the poor and the rich to save and invest and to the composition of domestic demand and its determinants. The proponents of the paradigm benefited largely from 
structuralists for macro issues such as the necessity to expand markets, but used also some elements of Maoism regarding asset redistribution. But the paradigm used extensively price theory at the micro level that gave it one of its distinctive features which is the balance between micro and macro issues.

\section{The Neo-Classical Paradigm}

The author traces the emergence of this paradigm to the period between the end of the nineteenth century and the beginning of the twentieth one, when it was founded on the principles of 'laissez faire' and the theory of comparative advantages as formulated by Ricardo. But the author devotes the chapter not to explain the paradigm of neo-classical theory in its entirety, it rather concerned specifically with the application of its perspectives in development economics. She starts with notes on early contributions made explicitly from the viewpoint of free trade and 'laissez faire' doctrine, and she considers Bauer \& Yamey (1957) to be maybe the first who wrote on development economics presenting a general overview of the causes of economic development from a neo-classical perspective.

She notices that subsequent contributions to development theory from this perspective were fragmentary and lack theoretical solidity in the sense that they mostly focused on specific issues, in a similar manner to the critics made by neo-classical to other development theories. For this she singles out the issues that she considers most important which are basically: trade and industrialization, the stabilization program of the International Monetary Fund, policy impact analysis, social cost-benefit analysis, macro-policy in developing countries, foreign aid and its impact on development, and others. The focus of the discussion is kept on positive contributions rather than on critiques levied against other development theories without avoiding totally the latter as sometimes some critiques prompted positive contribution.

The author then proceeds to provide a summary of recent criticisms levelled against the neo-classical paradigm classifying these criticisms under four main headings. She starts with critiques levied on its values and beliefs where she claims that those related to the roles of market, personal freedoms, and free markets were most implicitly or explicitly criticized, all before moving on to the criticisms on its assumptions. She extends the discussion to the critiques made against equilibrium economics and its irrelevance for the analysis of actual economic systems before turning to a presentation of specific criticisms written on specific contributions of the neo-classical economists to development economics.

Along the entire chapter, the author recognizes the micro emphasis of this theory and its focus on efficiency questions at the level of production units, but when it comes to development questions, its advocates ought to deal with macro questions especially the public economic policy and the role of government in the economy. Facing development questions, neo-classical economists were divided into two groups: one kept on supporting 'laissez faire' doctrine while others accepted government intervention in the economy to achieve goals related to economic efficiency, but the difference remained a matter of degree for which most of those who accepted government intervention did so on efficiency improvement ground. 


\section{Conclusion}

The author devotes this last chapter of the book to conduct interesting comparative analysis between the six paradigms. The comparisons are focused on compatibility and incompatibility between each paradigm and the others, highlighting shared and contradictory values, assumptions, analytical methodologies, conclusions and policy implications among the different six paradigms. She then highlights some points on future debate in development economics before ending the book with a paragraph on the possibility of eclecticism among different paradigms in the analysis of development and underdevelopment.

Without entering into much detail of the author' comparisons, we summarize the six singled out paradigms with reference to how each one has dealt with the following matters: the ultimate causes of underdevelopment, the key factors to development and the role of technology, the role of government, market and other institutions in the development process, and the implications for equality in the early stages of development.

The book reveals that the only paradigm that does not provide a clear definition of the process of development and underdevelopment is the neoclassical theory, which now still dominates textbooks in most western academia. This means that it is the only theory whose advocates have not looked deeply and consistently into the process of underdevelopment in order to understand its ultimate causes, and they have confined themselves to the analysis of specific problems in specific contexts. It mostly always approached development questions from the viewpoints of its main two central concepts: efficiency in resource allocation and technological change. Market and its invisible hand are regarded to be the most efficient allocators of resources in most cases, and so government intervention is only justified when there is a market failure. Apart from these few points, it is rare to find consensus in neoclassical literature on other issues related to development.

For the other five paradigms, it is interesting to note that all of them expect the government to play a central role in the development process especially in the early phases. However, they differ significantly in many other important aspects.

The modernization theory, or the paradigm of expanding capitalist nucleus, is the only theory that expects the possible repetition of development paths already undertaken by the currently advanced countries. By this theory, development is just a matter of time once the modern sector emerges and it is pace is determined by the technological advances in the modern sector. The paradigm is in line with the capitalist framework through relying on market forces as mechanisms for economic organization, but recommends a leading role of governments particularly during early stages of economic growth. The paradigm recommends the adoption of most advanced technologies as it regards them the main determinants of development's pace and regards the increased inequality, especially in the early phases of development, to be inevitable until the take-off is reached.

Structuralism and neo-Marxism both attribute the causes of the underdevelopment to the structure of the World trading system, set in favor of the interests of the advanced industrial countries (the centers) who extract the surplus from the underdeveloped countries (the 
peripheries), and this is the major point of agreement. However, while structuralism emphasizes the domestic market structures to be critical, neo-Marxist paradigm regards the pattern of class control over the economic surplus to be most important. Structuralists, therefore, aimed to play an active role in policy reform within the international economic system, while neo-Marxist paradigm concludes that the only path to development is through withdrawal from international capitalist system to take a socialist development path based on masses' control of economic surplus. However, neo-Marxism has said little about this socialist development path, despite the refusal of most, if not all, of its advocates to the soviet version of socialism. In other words, and differently from the structuralists, neo-Marxists never discussed in a systematic manner the degree of government involvement in the development process, the optimal choices technology and the nature of incentives system. A fact that the book author only mentioned in the conclusion chapter. Otherwise, we could legitimately question her classification of Maoism and neo-Marxism as two distinct paradigms.

With regard to technology, structuralists, like advocates of the paradigm of expanding capitalist nucleus, promotes the adoption of advanced/capital-intensive technology. The same applies to the question of increased inequality, which is also seen to be inevitable in the early stages of development by structuralists.

On the contrary, the basic needs paradigm attaches high importance to the small and medium-scale technologies that are labor-intensive, and do not accept the idea of inevitable increased inequality in the early stages of development. Despite their refusal to the political conclusions of neo-Marxism, they did not hesitate to adopt crucial elements of Maoist development strategy especially those drawn from the concept of growth with distribution. This is why many see this paradigm to be an implementation of Maoist strategy in the context of market economy relying on pure economic incentive systems, contrary to the Maoism that based its development plans, for substantial periods of time, on non-material incentives in the context of the so-called the "masses line". However, one important difference between the two, which was not noted clearly in the book, is that Maoism has been always concerned with the technological catch-up with the Western advanced countries. This preoccupation has let, at the beginning, to the Chinese focus on heavy industries before the recognition of the roles of light and medium industries in generating stable incomes for the masses that led to the strategy of "walking on two legs".

\section{Final Comment}

Despite being around 25 years old, the book is still relevant. It is relevant for students of development economics who are willing to, or maybe should, widen their theoretical perspectives beyond what is prevalent in official academia especially in Western Countries. For those the book is a good introduction to alternative economic thoughts that help students better see the shortcomings of the dominant neo-classical theory. In addition, the book is relevant for policy analysts and development planners in developing countries where it can serve as a reference to better understand the context in which past policies, in many parts of the World, were formulated and why these policies may be outdated now. Furthermore, the 


\section{Macrothink

book might be relevant for scholars of ideology and potential links between economic, social, political and ideological aspects of development. Least but not last, the book is a recommended reference for other social scientists and general intellectuals whose background in economics is not academic. The relatively simple jargon in which the book is written makes it easily readable and understandable by interested people from outside the fields of economics. This might be necessary to enrich the debate to take into consideration the viewpoints of other related disciplines.

\section{Acknowledgements}

This essay was written as part of the activities of research fellowship financed by International Institute for Education/Scholar Rescue Fund (IIE-SRF). The fellowship was hosted and partially funded by the Department of Economics and Development/University of Florence. Thanks to Prof. Donato Romano for his valuable advice.

\section{References}

Adelman, I. (1975). Development Economics: A reassessment of goals. American economic Review, 65(2), 302-309.

Amin, S. (1974). Accumulation on a World Scale. Monthly Review Press.

Baran, P. (1957). The Political Economy of Growth. Monthly Review Press.

Bauer, P. T., \& Yamey, B. (1957). The Economics of Underdeveloped Countries. Cambridge.

Dag Hammarskjöld Foundation Report. (1975). What now? Another development. Uppsala.

Dos Santos, T. (1970). The structure of dependence. American Economic Review, 60(2), 231-236.

Frank, A. G. (1978). Dependent Accumulation and Underdevelopment. Macmillan.

Furtado, C. (1976). Economic Development of Latin America: Historical Background and Contemporary Problems (2nd ed.). Cambridge.

Grant, J. (1978). Disparity Reduction Rates in Social Indicators. Oversees Development Council.

Hirschman, A. (1958). The Strategy of Economic Development. Yale.

Kuhn, T. (1962). The Structure of Scientific Revolutions (2nd ed.). University of Chicago Press.

Lefeber, L. (1974). On the Paradigm if Economic Development. In A. Mitra (Ed.), Economic Theory and Planning. Oxford.

Lewis, W. A. (1954). Economic development with unlimited supplies of labour. Manchester School; reprinted in Agarwala, A., \& Singh, S. (Eds.), the Economics of Underdevelopment, Oxford, 1963. http://dx.doi.org/10.1111/j.1467-9957.1954.tb00021.x

Morris, M., \& Liser, F. (1977). The PQLI: measuring progress in meeting human needs. Communique on Development Issues. No. 32. Oversees Development Council. Washington 
DC.

Myint, H. (1954). An interpretation of economic backwardness, Oxford Economic Papers, reprinted in Agarwala, A., \& Singh, S (Eds.), the Economics of Underdevelopment, Oxford, 1958.

Myrdal, G. (1957). Economic Theory and Underdeveloped Countries. Duckworth.

Nurkse, R. (1953). Problems of Capital Formulation in Underdeveloped Countries. Blackwell.

Prebisch, R. (1949). The economic development of Latin America and its principal problems. Economic Bulletin of Latin America. Vol. VII, No, pp 1-22. 1 February 1962; first published in 1949 .

Ranis, G., \& Fei, G. (1961). A theory of economic development. American Economic Review, 51(4), 533-565.

Rosenstein-Rodan, P. (1943). Problems of industrialization of Eastern and South-eastern Europe. Economic Journal. Vol. 53, No. 210/211, pp. 202-211. Reprinted in Agarwala, A., \& Singh, S. (Eds.), the Economics of Underdevelopment, Oxford, 1958. http://dx.doi.org/10.2307/2226317

Rostow, W. (1953). The Process of Economic Growth. Clarendon Press, Oxford.

Rostow, W. (1956). The take-off into self-sustained growth. Economic Journal. Vol. 66, No. 261, pp. 25-48. Reprinted in Agarwala, A., \& Singh, S. (Eds.), the Economics of Underdevelopment, Oxford, 1958. http://dx.doi.org/10.2307/2227401

Seers, D. (1981). Dependency Theory: A Critical Assessment. Frances Printer.

Seers, D. (1972). What are we trying to measure? Journal of Development Studies. Vol. 8, No. 3, pp. 21-36. Reprinted in Baster, N. (Ed.), Frank Cass. 1972.

Singer, H. (1950). The distribution of gains between investing and borrowing countries. American Economic Review. Papers and Proceedings. Vol. 40, No. 4.

Stewart, F. (1985). Planning to Meet Basic Needs. Macmillan.

Sunkel, O. (1973). Transnational capitalism and national disintegration in Latin America. Social and Economic Studies, 22(1), 156-171.

Warren, B. (1980). Imperialism: Pioneer of Capitalism. Verso.

\section{Copyright Disclaimer}

Copyright for this article is retained by the author(s), with first publication rights granted to the journal.

This is an open-access article distributed under the terms and conditions of the Creative Commons Attribution license (http://creativecommons.org/licenses/by/3.0/). 